\title{
Isolasi dan Identifikasi Salmonella pada Daging Sapi di Rumah Potong Hewan Banyuwangi
}

\author{
Isolation and Identification of Salmonella from Meat in Banyuwangi Abattoir \\ Dwi Putri Indriyani ${ }^{1 *}$, Wiwiek Tyasningsih ${ }^{2}$, Ratih Novita Praja ${ }^{2}$ \\ ${ }^{1}$ Pendidikan Profesi Dokter Hewan, \\ ${ }^{2}$ Departemen Mikrobiologi Veteriner, \\ Fakultas Kedokteran Hewan, Universitas Airlangga, \\ Kampus C Mulyorejo, Surabaya, Jawa Timur, Indonesia 60115 \\ *Corresponding author: dwiputriindriyani96@gmail.com
}

\begin{abstract}
Abstrak
Tujuan penelitian ini adalah untuk mengetahui keberadaan Salmonella kontaminasi pada sapi potong yang disembelih di Rumah Potong Hewan (RPH) Banyuwangi. Sampel yang digunakan dalam penelitian ini adalah daging sapi yang diambil pada Januari 2018 yang disembelih di RPH Banyuwangi. Penelitian ini mengambil 25 gram musculus paha dari daging sapi digunakan sebagai sampel dan jumlah sampel adalah 32 sampel daging sapi yang diambil dari pemotongan sapi di RPH Banyuwangi. Hasil uji isolasi dan identifikasi menggunakan IMVIC menunjukkan bahwa 3.1\% sampel positif Salmonella spp. sedangkan persentase sampel negatif Salmonella spp. adalah 96.9\%. Hasil penelitian menunjukkan bahwa dengan hasil sampel positif 3.1\% menunjukkan adanya Salmonella spp. ini bisa jadi karena RPH Banyuwangi sebagai tempat pengambilan sampel memiliki sanitasi yang lebih baik sehingga tingkat kontaminasi yang terjadi tidak terlalu tinggi.
\end{abstract}

Kata kunci: daging sapi, Salmonella spp, rumah potong hewan

\section{Abstract}

The aim of this study was to determine the presence of Salmonella spp. contamination on the beef of cattle slaughtered at Banyuwangi abattoir. Isolation and identification of Salmonella spp. were done to provide Safe, Healthy, intact and Halal beef for the people of Banyuwangi. The sample in this study was beef meat which taken in January 2018 from Banyuwangi abattoir. In this study, 25 grams of thigh musculus from the meat used as a sample and the number of samples was 32 samples. The results of the isolation and identification showed that 3.1\% samples positive of Salmonella spp., while the percentage of negative samples of Salmonella spp. was $96.9 \%$. The result of $3.1 \%$ positive samples indicates the presence of Salmonella spp. can be caused by the low contamination rate. Banyuwangi abattoir as a place for sampling has better sanitation.

Key words: beef, Salmonella spp, abattoir

Received: 22 Maret 2019

Revised: 12 April 2019

Accepted: 11 Juli 2019

\section{PENDAHULUAN}

Daging sapi merupakan komoditas daging yang disukai masyarakat Indonesia (Nurwanto et al., 2012). Kandungan daging sapi terdiri atas $19 \%$ protein, $5 \%$ lemak, $75 \%$ air, dan $3.5 \%$ zatzat non protein (Lawrie, 2003). Kebutuhan daging sapi yang semakin meningkat menuntut produksi dan perhatian lebih terhadap daging sapi yang berkualitas (Jonsen, 2004). Penyediaan daging sapi yang Aman, Sehat, Utuh, dan Sehat (ASUH) sangat diharapkan dalam memenuhi persyaratan Batas Maksimum Cemaran Mikroba (BMCM) sehingga diperoleh daging yang kandungan mikrobanya tidak melebihi batas (Susanto dkk, 2013). Mutu karkas juga sangat dipengaruhi dengan kondisi lingkungan, sarana dan prasarana pemotongan pada Rumah Potong Hewan (RPH) (Gustiani, 2009). Sumber kontaminasi bakteri dimulai pada saat pemotongan hewan sampai daging dikonsumsi. Rumah Potong Hewan (RPH) dan pasar tradisional menjadi kemungkinan terbesar daging dapat terkontaminasi bakteri. 
Suatu produk pangan hewani aman dikonsumsi jika tidak mengandung bakteri patogen, hal ini sangat berbahaya karena dapat menimbulkan penyakit pada manusia akibat mengkonsumsi pangan asal hewan yang terkontaminasi bakteri patogen tersebut yang dikenal dengan istilah Food Borne Disease (Syarifah dkk, 2015). Bakteri patogen yang seringkali menjadi penyebab Food Borne Disease adalah Salmonella spp. Gejala penyakit yang dialami antara lain rasa mual, diare, kram perut, demam, menggigil, sakit kepala dan muntah yang ditimbulkan 8-72 jam setelah mengkonsumsi pangan yang tercemar (Jay dkk, 2005). Berdasarkan besarnya resiko yang disebabkan oleh infeksi Salmonella spp. maka perlu dilakukan pengawasan terkait cemaran bakteri pada daging sapi di RPH guna menjaga kualitas dan keamanan pangan bagi masyarakat.

Penelitian ini bertujuan untuk melakukan studi terkait keberadaan Salmonella spp. pada daging sapi di RPH Banyuwangi agar aman dan layak untuk dikonsumsi. Hasil penelitian ini diharapkan dapat digunakan sebagai bahan pertimbangan bagi instansi terkait dalam menetapkan kebijakan, dan pengawasan yang lebih intensif terhadap bahan pangan asal hewan.

\section{METODE PENELITIAN}

Penelitian dilaksanakan pada tanggal 1-31 Januari 2019. Pengambilan sampel dilakukan di RPH Banyuwangi pada pukul 00.00-03.00 WIB. Pengujian sampel dilakukan di Laboratorium Instrumen, Universitas Airlangga Progam Studi Diluar Kampus Utama Banyuwangi. Pengambilan sampel dilakukan dengan Teknik purposive sampling dan data yang diperoleh dianalisis secara deskriptif. Pengambilan sampel daging sapi bagian paha sebanyak 32 sampel dilakukan setiap hari kamis dan minggu. Setiap sampel dipisahkan dalam wadah cawan steril kemudian dibawa ke laboratorium menggunakan cool box untuk dilakukan pengujian.

Daging sapi diperiksa menggunakan prinsip pengujian bakteri Salmonella spp meliputi tahap isolasi pada media selektif dengan pra pengayaan, pengayaan dilanjutkan dengan identifikasi melalui uji biokimia. Tahap pertama adalah pra-pengayaan yang dilakukan dengan cara setiap sampel daging sapi ditimbang $25 \mathrm{~g}$ kemudian dimasukkan dalam Erlenmeyer dan ditambahkan $225 \mathrm{ml}$ larutan Lactose Broth (LB) aduk perlahan dilanjutkan proses inkubasi pada suhu $35^{\circ} \mathrm{C}$ selama $24 \pm 2$ jam. Tahap kedua pengayaan, biakan pra-pengayaan diaduk perlahan kemudian dipindahkan masing-masing $1 \mathrm{ml}$ ke dalam media $10 \mathrm{ml}$ Tethrathionate Broth (TTB) dan diinkubasi pada suhu $35^{\circ} \mathrm{C}$ selama $24 \pm 2$ jam (SNI, 2008).

Tahap isolasi dilakukan dengan cara menggoreskan biakan pada tahap pengayaan pada media Salmonella-Shigella Agar (SSA). Bakteri yang diduga Salmonella spp. menunjukkan koloni yang tidak berwarna maupun membentuk black spot pada sentral koloni (Sarudji dkk. 2018). Koloni yang diduga Salmonella spp. pada media SSA dilanjutkan pada tahap konfirmasi melalui uji biokimia dengan media Triple Sugar Iron Agar (TSIA), Methyl Red-Voges Proskauer (MR-VP), Simmon's Citrate Agar (SCA), Sulfide Indol Motility (SIM), dan uji gula-gula menggunakan media laktosa, sukrosa dan glukosa (SNI, 2009; SNI, 2008).

Data yang diperoleh dari cemaran bakteri Salmonella dianalisis secara deskriptif. Hasil yang diperoleh kemudian dibandingkan dengan batas Standar Nasional Indonesia (2009) yaitu Salmonella spp. Negative per 25 gram sampel.

\section{HASIL DAN PEMBAHASAN}

Pelabelan daging sapi diberikan angka (132) kemudian diuji menggunakan metode yang telah ditetapkan. Hasil penelitian ini diperoleh sebanyak 26 sampel diduga menunjukkan koloni spesifik Salmonella spp. pada media SSA. Sampel yang diduga Salmonella spp. kemudian diidentifikasi menggunakan media TSIA, uji IMVIC dan uji gula-gula. Berdasarkan data, 1 sampel (3.1\%) menunjukkan positif Salmonella spp. dan 31 sampel (96.9\%) menunjukkan negatif Salmonella spp. (Tabel 1).

RPH Banyuwangi perlu memperhatikan hygine dan sanitasi agar mencegah kontaminasi 
Tabel 1. Hasil isolasi dan identifikasi Salmonella spp.

\begin{tabular}{|c|c|c|c|c|c|c|c|c|c|c|}
\hline No & SSA & TSIA & SIM & SCA & MR & VP & Glu & Lac & Suc & Hasil \\
\hline 1 & + & $\mathrm{M} / \mathrm{K} /+/+$ & $\mathrm{H} 2 \mathrm{~S}+$ /indol+ & + & + & - & + & + & + & - \\
\hline 2 & + & $\mathrm{M} / \mathrm{K} /+/+$ & $\mathrm{H} 2 \mathrm{~S}+/$ indol+ & + & - & - & + & + & + & - \\
\hline 3 & + & $\mathrm{M} / \mathrm{K} /+/+$ & $\mathrm{H} 2 \mathrm{~S}+$ /indol+ & + & + & - & + & - & - & Salmonella spp. \\
\hline 4 & + & $\mathrm{M} / \mathrm{K} /+/-$ & $\mathrm{H} 2 \mathrm{~S}+$ /indol+ & + & + & - & + & + & + & - \\
\hline 5 & + & $\mathrm{K} / \mathrm{K} /+/+$ & - & - & - & - & - & - & - & - \\
\hline 6 & + & $\mathrm{M} / \mathrm{K} /+/-$ & $\mathrm{H} 2 \mathrm{~S}+$ /indol+ & + & + & - & - & + & + & - \\
\hline 7 & + & $\mathrm{K} / \mathrm{K} /+/+$ & - & - & - & - & - & - & - & - \\
\hline 8 & + & $\mathrm{M} / \mathrm{K} /+/-$ & $\mathrm{H} 2 \mathrm{~S}+$ /indol+ & + & + & - & + & + & + & - \\
\hline 9 & - & - & - & - & - & - & - & - & - & - \\
\hline 10 & + & $\mathrm{K} / \mathrm{K} /+/+$ & - & - & - & - & - & - & - & - \\
\hline 11 & + & $\mathrm{M} / \mathrm{K} /+/-$ & $\mathrm{H} 2 \mathrm{~S}+$ /indol+ & + & - & - & + & + & + & - \\
\hline 12 & + & $\mathrm{M} / \mathrm{K} /+/-$ & $\mathrm{H} 2 \mathrm{~S}+$ /indol+ & + & - & - & + & - & + & - \\
\hline 13 & + & $\mathrm{M} / \mathrm{K} /+/-$ & $\mathrm{H} 2 \mathrm{~S}+$ /indol+ & + & - & - & + & + & + & - \\
\hline 14 & - & - & - & - & - & - & - & - & - & - \\
\hline 15 & + & $\mathrm{K} / \mathrm{K} /+/+$ & - & - & - & - & - & - & - & - \\
\hline 16 & + & $\mathrm{K} / \mathrm{K} /+/-$ & - & - & - & - & - & - & - & - \\
\hline 17 & + & $\mathrm{M} / \mathrm{K} /+/-$ & $\mathrm{H} 2 \mathrm{~S}+$ /indol+ & + & - & - & + & + & + & - \\
\hline 18 & + & $\mathrm{K} / \mathrm{K} /+/-$ & - & - & - & - & - & - & - & - \\
\hline 19 & + & $\mathrm{M} / \mathrm{K} /+/-$ & $\mathrm{H} 2 \mathrm{~S}+$ /indol+ & + & - & - & + & + & + & - \\
\hline 20 & + & $\mathrm{K} / \mathrm{K} /+/-$ & - & - & - & - & - & - & - & - \\
\hline 21 & + & $\mathrm{M} / \mathrm{K} /+/+$ & $\mathrm{H} 2 \mathrm{~S}+$ /indol+ & + & + & - & + & + & + & - \\
\hline 22 & + & $\mathrm{K} / \mathrm{K} /+/+$ & - & - & - & - & - & - & - & - \\
\hline 23 & + & $\mathrm{K} / \mathrm{K} /+/+$ & - & - & - & - & - & - & - & - \\
\hline 24 & + & $\mathrm{M} / \mathrm{K} /+/+$ & $\mathrm{H} 2 \mathrm{~S}+$ /indol+ & + & - & - & + & + & + & - \\
\hline 25 & + & $\mathrm{K} / \mathrm{K} /+/+$ & - & - & - & - & - & - & - & - \\
\hline 26 & + & $\mathrm{M} / \mathrm{K} /+/-$ & $\mathrm{H} 2 \mathrm{~S}+$ /indol+ & + & - & - & + & + & + & - \\
\hline 27 & - & - & - & - & - & - & - & - & - & - \\
\hline 28 & + & $\mathrm{M} / \mathrm{K} /+/+$ & $\mathrm{H} 2 \mathrm{~S}+/$ indol+ & + & - & - & + & + & + & - \\
\hline 29 & - & - & - & - & - & - & - & - & - & - \\
\hline 30 & + & $\mathrm{K} / \mathrm{K} /+/+$ & - & - & - & - & - & - & - & - \\
\hline 31 & - & - & - & - & - & - & - & - & - & - \\
\hline 32 & - & - & - & - & - & - & - & - & - & - \\
\hline
\end{tabular}

Keterangan:

$\mathrm{SSA}=$ Salmonella Shigela Agar; TSIA= Triple Sugar Iron Agar; SIM= Sulfide Indol Motility; SCA= Simmon's Citrate Agar; MR= Methyl Red; $\mathrm{VP}=$ Voges Proskauer $; \mathrm{Glu}=$ Glukosa; Lac= Laktosa; $\mathrm{Suc}=$ Sukrosa; M= Merah; K= Kuning

bakteri Salmonella spp. pada daging sapi. Sampel daging yang positif adalah sampel dengan label nomer 3 dimana kondisi RPH Banyuwangi belum dilakukan renovasi (Tabel 1). Berbeda dengan sampel yang diambil pada minggu selanjutnya dimana kondisi RPH Banyuwangi telah dilakukan renovasi dan sanitasi lingkungan lebih diperhatikan sehingga berdampak pada tidak ditemukannya kontaminasi bakteri Salmonella spp. pada daging sapi.

Jaringan hewan sehat umumnya bebas dari bakteri pada saat dipotong, tetapi lingkungan dengan hygine dan sanitasi yang kurang baik daging segar tidak jarang terkontaminasi oleh berbagai jenis dan jumlah mikroorganisme (Jay et al., 2005). Permukaan daging yang baru disembelih biasanya mengandung sekitar $10^{2}-10^{4}$ bakteri per inci terutama terdiri dari bakteri mesofilik yang berasal dari saluran pencernaan dan permukaan luar hewan tersebut (Saptarini, 2009). Bakteri yang paling banyak mengkontaminasi daging, yakni: Enterococcus, Acinetobacter, Aeromonas, Micrococcus, Moraxella, Leuconostoc, Lactobacillus, Bacillus, Flavobacterium, Clostiridium, Escherichia, 
Campylobacter dan Salmonella (Angraeini, 2005).

Kemampuan pertumbuhan mikroorganisme pada daging dipengaruhi oleh faktor intrinsik dan faktor ektrinsik. Faktor intrisik meliputi ketersediaan nutrisi, pH (Potential Hidrogen), aktivitas air $\left(a_{w}\right)$ yang terdapat dalam daging, potensi oksidasi-reduksi dan ada tidaknya substansi penghambat mikroorganisme. Faktor ekstrinsik meliputi suhu ruang penyimpanan, kelembaban relative dan kondisi oksigen atmosfer (Jay et al., 2005).

Menurut Soeparno (2005) daging memenuhi persyaratan untuk perkembangan mikroorganisme perusak dan pembusuk karena mempunyai kadar air yang tinggi (68-75\%). Air merupakan konstituen utama cairan ekstraseluler yang di dalamnya terdapat senyawa kimia yang terlarut maupun tersuspensi. Air merupakan medium transportasi diantara serat daging sehingga kadar air berperan penting pada kehidupan mikroorganisme (Soeparno, 2005). Daging kaya akan zat yang mengandung nitrogen dengan kompleksitas yang berbeda serta mengandung sejumlah karbohidrat yang dapat difermentasikan oleh bakteri. Daging memiliki kandungan mineral dan kelengkapan faktor untuk pertumbuhan mikroorganisme dalam daging serta $\mathrm{pH}$ yang menguntungkan bagi sejumlah mikroorganisme ( $\mathrm{pH}$ sekitar 5,3-6,5) (Fikri et al., 2017).

Salmonella merupakan bakteri yang sering mengontaminasi makanan seperti telur dan hasil olahannya, ikan dan hasil olahannya, daging ayam, daging sapi, serta susu dan hasil olahannya seperti es krim dan keju (Jay et al., 2005). Salmonella merupakan bakteri patogen yang dapat menyebabkan keracunan pangan. Semua jenis Salmonella merupakan patogen fakultatif intraseluler dan dianggap sangat patogenik (Bhunia, 2008). Ditemukannya bakteri Salmonella spp. pada sampel nomor 3 yang diambil dari daging sapi di RPH Banyuwangi belum sesuai dengan SNI 7388:2009 yaitu negatif per 25 gram untuk Salmonella spp (SNI, 2009). Kontaminasi pada daging sapi berasal dari faktor kurang bersihnya kondisi peralatan di RPH yang digunakan selama mempersiapkan karkas (Huda, 2016; Fikri et al., 2018). Menurut Mosupye and Holy (2005) kontaminasi awal pada daging berasal dari mikroorganisme yang memasuki peredaran darah pada saat penyembelihan, setelah proses penyembelihan kontaminasi selanjutnya dapat terjadi pada saat pengulitan, pengeluaran jeroan, pembelahan karkas, preservasi, penyimpanan dan distribusi. Di sisi lain, ketika proses pengeluaran jeroan dan pembelahan karkas, maka tumpahan rumen dan cairan usus dapat mencemari pekerja (Bloomfield dkk., 2007).

Menurut Abdalla et al.,, (2009) lantai di RPH yang digunakan selama proses pengolahan karkas, secara signifikan menjadi sarana untuk terjadinya kontaminasi oleh Salmonella spp. Studi yang dilakukan di india, menunjukkan bahwa lantai, bentuk plat lantai, dan dinding adalah tempat paling sering terjadinya kontaminasi oleh bakteri. Selain itu kontaminasi oleh bakteri juga berasal dari kotoran, darah, dan cairan yang keluar dari viscera yang kemudian menempel pada lantai dinding, hal ini secara signifikan menjadi pencemar pada daging yang telah dipotong (Bhandare et al., 2009). Menurut Steven et al.,, (2006) pencemaran Salmonella spp. pada daging yang paling sering biasanya terjadi selama proses pemotongan hewan yaitu alat yang digunakan dalam dressing (pisau, alatalat yang digunakan untuk membelah dan alat pengait), air (air yang digunakan mencuci karkas atau untuk membersihkan lantai), kulit, saluran pencemaran (bila secara tidak sengaja keluar pada saat dressing) merupakan hal- hal yang dapat menyebabkan terjadinya kontaminasi terhadap daging (Lawrie and Ledward, 2006). Terjadinya peningkatan jumlah bakteri pada daging tergantung pada penanganan dan tingkat pencemaran selanjutnya. Pembentukan lendir dan bau busuk merupakan indikator adanya perkembangan bakteri pada daging. (Buck et al., 2009; Kartikasari et al., 2019).

Pelaksanaan dan penyediaan daging di RPH merupakan salah satu penentu dari kualitas dan keamanan daging. Proses penanganan ternak dan daging di RPH yang kurang baik dan tidak memperhatikan faktor-faktor sanitasi dan higienis, akan berdampak pada mutu, kehalalan 
dan keamanan daging yang dihasilkan. Penetapan aturan atau standar operasional maupun teknis sebagai dasar untuk menyelenggarakan fungsi RPH sebagai tempat pelaksanaan pemotongan ternak guna menghasilkan daging yang ASUH (Kuntoro, 2012). Daging merupakan salah satu produk pangan asal hewan yang memiliki kandungan nilai gizi tinggi, hal tersebut sangat mendukkung bagi kehidupan mikroorganisme terutama bakteri. Adanya aktifitas bakteri dalam daging akan menurunkan kualitas daging yang ditunjukkan dengan perubahan warna, rasa, aroma dan pembusukkan yang dipengaruhi oleh kondisi ternak, kondisi lingkungan, kondisi tempat pemotongan dan proses penanganan daging mulai dari pemotongan sampai pengolahan (Kuntoro, 2012).

\section{KESIMPULAN}

Terdapat 1 sampel (3.1\%) menunjukkan positif Salmonella dan 31 sampel (96.9\%) negatif Salmonella pada sampel daging sapi yang diambil di RPH Banyuwangi.

\section{UCAPAN TERIMA KASIH}

Penulis mengucapkan terimakasih kepada Universitas Airlangga PSDKU Banyuwangi atas dukungan fasilitas sehingga penelitian ini dapat diselesaikan. Peneliti juga mengucapkan terimakasih kepada dosen pembimbing yang telah membantu sehingga seluruh kegiatan dapat dilaksanakan dengan baik.

\section{DAFTAR PUSTAKA}

Abdalla, M.A, Suliman, S.E., Ahmed, D.E, and Bakhiet A.O. 2009. Estimation of Bacterial contamination of Indigenous Bovine Carcasses in Khartoum. Afr. J. Microbiol. Res. Sudan., 3, 882-886.

Anggraeni, Y. 2005. Sifat Fisik Daging Dada Ayam Broiler Pada Berbagai Lama Postmortem Disuhu Ruang [Skripsi].
Fakultas Teknologu Pertanian. Institut Pertanian Bogor.

Badan Standardisasi Nasional. 2008. Metode Pengujian Cemaran Mikroba dalam Daging, Telur, dan Susu, serta Hasil Olahannya. SNI 2897-2008. Jakarta.

Badan Standarisasi Nasional. 2009. Batas Maksimum Cemaran Mikroba Dalam Pangan. SNI 7388:2009. Jakarta.

Bhandare, S.G., Paturkar, A.M., Waskar, V.S., Zende, R.J. 2009. Bacteriological screening of environmental sources of contamination in an abattoir and the meat shops in Mumbai. As. J. Food Agro., 2, 280-290.

Bhunia, A. 2008. Foodborne Microbial Pathogens. Springer. USA.

Bloomfield, S.F., Aiello, A.E., Cookson, B., Boyle, C.O., Larson, E.L. 2007. The effectiveness of hand hygiene procedures in reducing the risks of infections in home and community settings including hand washing and alcohol based hand sanitizer. Am. J. Infect. Control., 35, 27-64.

Buckle K.A., Edwards, R.A., Fleet, G.H., Wootton, M. 2009. Ilmu Pangan. Hari Purnomo dan Adiano. Penerjemah: Jakarta: Universitas Indonesia Press. Terjemahan dari : Food Science.

Fikri, F., Hamid, I.S., Purnama, M.T.E. 2017. Uji organoleptis, $\mathrm{pH}$, uji eber dan cemaran bakteri pada karkas yang diisolasi dari kios di Banyuwangi. J. Med. Vet., 1(1), 23-27.

Fikri, F., Purnama, M.T.E., Saputro, A.L., Hamid, I.S. 2018. Identifikasi Escherichia coli dan Salmonella spp pada Karkas Sapi di Rumah Potong Hewan di Banyuwangi dan Resistensi Terhadap Antibiotika. J. Sain Vet., 36(1), 123-128. 
Gustiani, E. 2009. Pengendalian Cemaran Mikroba Pada Bahan Asal Ternak (daging dan susu) Mulai Dari Peternakan Sampai dihidangkan. J. Litbang. Pertanian, 28(3), 9.

Huda, M.S.M. 2016. Isolasi dan Identifikasi Salmonella sp. Pada daging sapi hasil penyembelihan dari rumah pemotongan hewan (RPH) Pegirian Kota Surabaya [Skripsi]. Fakultas Kedokteran Hewan. Universitas Airlangga.

Jay, J.M., Loessner, M.J., Golden, D.A. 2005. Modern Food Microbiology. Seventh Edition. USA. Springer Science and Bussuness Media Inc. p473-495.

Jonsen, G.D. 2004. Prospek dan Preferensi Masyarakat Terhadap Konsumsi Daging Sapi Olohan Di Indonesia. S. FGW FOOD Conference. Jakarta 6-7 Oktober 2004.

Kartikasari, A.M., Hamid, I.S., Purnama, M.T.E., Damayanti, R., Fikri, F., Praja, R.N. 2019. Isolasi dan Identifikasi Bakteri Escherichia coli Kontaminan Pada Daging Ayam Broiler Di Rumah Potong Ayam Kabupaten Lamongan. J. Med. Vet., 2(1), 66-71.

Kuntoro B., Maheswari, R.R.A., Nuraini, H. 2012. Hubungan Penerapan Standar Sanitation Operasional Procedure (SSOP) Terhadap Mutu Daging. Ditinjau dari Tingkat Cemaran Mikroba. J. Ilmiah IlmuIlmu Peternakan, 15(2), 70-80.

Lawrie, R.A. 2003. Ilmu Daging. Edisi kelima. Universitas Indonesia Press, Jakarta.

Lawrie, R.A., Ledward, D.A. 2006. Lawrie's Meat Science. Cambridge: Woodhead Pub.
Mosupye, F.M., Holy, A. 2005. Microbiologycal Hazzard Identification and Exposure Assessment of street food vending in johannesburg. Dapartement of Moloculer an Cell Biology. University of the Witwatersrand.

Saptarini, K. 2009. Isolasi Salmonella spp. pada Sampel Daging Sapi di Wilayah Bogor Serta Uji Ketahanannya Terhadap Proses Pendinginan dan Pembekuan [Skripsi]. Fakultas Teknologi Pertanian. Institut Pertanian Bogor.

Sarudji, S., Chusniati, S., Tyasningsih, W., Handijatno, D. 2018. Petunjuk Praktikum Penyakit Infeksius I Progam S-1 Kedokteran Hewan.

Soeparno. 2005. Ilmu dan Teknologi Daging. Edisi Ke-4. Yogyakarta. Gadjah Mada University Press.

Stevens, A., Kabore, Y., Perrier, J.D., Brisabois, A., Catteau, M., Cavin, F.J., Dufour, B. 2006. Prevelance and antibiotic resistance of Salmonella isolated froom beef sampled from the slaughterhouse and from retailers in Dakar. Int. J. Food Microbiol., 110, 178-186.

Susanto, E., Wenny, L. 2013. Analisis Kualitas Mikrobiologis Daging Sapi di Pasar Tradisional Kota Lamongan. J. Ternak.

Syarifah, I., Novarieta, E. 2015. Deteksi Salmonella sp. pada Daging Sapi dan Ayam. Prosiding Seminar Nasional Teknologi Peternakan dan Veteriner. 